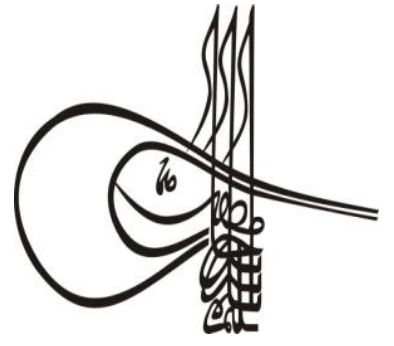

Received/Geliș: 28.06 .2019

\section{Turkish Studies \\ Social Sciences}

Volume 14 Issue 4, 2019, p. 1435-1445

DOI: 10.29228/TurkishStudies.23423

ISSN: 2667-5617

Skopje/MACEDONIA-Ankara/TURKEY

Research Article / Araştırma Makalesi

Article Info/Makale Bilgisi

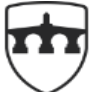

INTERNATIONAL BALKAN UNIVERSITY

EXCELLENCE FOR THE FUTURE IBU.EDU.MK

Gor Report Dates/Rapor Tarihleri: Referee 1 (26.07.2019)-Referee 2 (26.07.2019)

This article was checked by iThenticate.

\title{
JOHN LOCKE VE JOHN RAWLS'UN KURAMLARINDA ADALET DÜŞÜNCESİ: SÖZLEŞME VE RASYONALİTE
}

\author{
Özlem DENLI $\dot{I}^{*}$
}

\begin{abstract}
öz
$\mathrm{Bu}$ makalenin konusu John Locke ve John Rawls'un kuramlarında karşımıza çıkan adalet anlayışlarıdır. Locke klasik liberalizmin kurucu babaları arasında yer alırken, Rawls da geleneğin 20. yüzyılda yaşadığı yeniden doğuş ve artan görünürlük ile ilişkilendirilen bir isimdir. İncelemede izlenecek yol iki ana eksen etrafında kurgulanmıştır. İlk eksen, adalet kavramını çerçeveleyen genel kuramsal yapıların genel hatlarıyla ortaya çıkarılmasına tekabül eder. İkinci eksen ise adalet fikrinin şekillenmesinde rol oynayan eşitlik, özgürlük, rıza, sözleşme ve rasyonalite kavramlarının tartışmaya dâhil edilmesini gerektirmektedir. Bunlar arasından sözleşme ve rasyonalite temaları Locke ve Rawls'un adalet anlayışlarının benzeştiği ve farklılaştığı zeminlerin ana unsurları olarak vurgulanacak ve özel bir ağırlıkla ele alınacaktır. Rawls tartışması düşünürün erken dönem çalışmalarıyla sınırlı olarak yürütülecek ve esas olarak Bir Adalet Teorisi isimli esere yoğunlaşacaktır. Bu tercihin nedeni Rawls'un geç dönem eserlerinde rastlanan kuramsal yön değiştirmenin makalenin kapsamı dışında bırakılmasıdır. Eşitlik ve özgürlük fikirleri her iki düşünürün de adalet kavramsallaștırmaları açısından temel bir başlangıç noktası teşkil eder ve eşit özgürlük ya da özgürlükte eşitlik olarak tarif edebileceğimiz bir kavram seti olarak tanımlanabilir. Benzer biçimde rasyonalite fikri de merkezi bir önem ve işleyişe sahiptir. Hem Locke hem de Rawls için rasyonalite bireyleri tanımlayan bir özellik olmanın yanı sıra, onları sözleşme aracılığıyla adalet arayışına yönlendiren temel bir niteliktir. Bu anlamda adil bir toplumsal yapının inşa edilmesi Locke açısından doğal hakların daha güçlü koruması, Rawls içinse toplumsal işbirliğinin sağladığı faydalar açısından rasyonel sayılmaktadır.
\end{abstract}


Anahtar Kelimeler: John Locke, John Rawls, liberalizm, liberal adalet anlayışı, toplum sözleşmesi, bireysel haklar, eşitlik, özgürlük, rasyonalite.

\title{
THE CONCEPT OF JUSTICE IN THE WORKS OF JOHN LOCKE AND JOHN RAWLS: CONTRACT AND RATIONALITY
}

\begin{abstract}
The topic of this essay is the concept of justice in the works of John Locke and John Rawls; the former being the foremost figure associated with classical liberalism, and the latter being associated with the liberal renaissance of the $20^{\text {th }}$ century. I approach the subject by way of 1) delineating the theoretical frameworks put forward by the thinkers, and 2) explicating the concept of justice in connection with some adjacent ideas such as equality, freedom, consent, contract, and rationality. I accept the last two items on the list as particularly significant, and deal with them with special emphasis. In the case of Rawls, the discussion is limited to his early works, A Theory of Justice in particular; since his later writing are characterized by a theoretical turn towards incorporating certain elements of communitarian thought. For both Locke and Rawls, the freedom and equality of human beings operates as a foundational assumption. These concepts carry value and significance by themselves, and seem, furthermore, to combine into the notion of equality in liberty. The idea of rationality in this context appear to be a defining feature of the individual on the one hand, and as a capacity motivating the terms of social cooperation on the other. For Locke and Rawls respectively, contracting into a just society falls in line with rationality by virtue of enabling better protection for natural rights or by enabling the individual to enjoy the benefits of fair social cooperation.
\end{abstract}

\section{STRUCTURED ABSTRACT}

The topic of this essay is the concept of justice in the works of two prominent liberal thinkers; John Locke and John Rawls. Locke is accepted as one of the founding fathers of contractual liberal thought, alongside with Thomas Hobbes and Jean Jacques Rousseau. Nonetheless, he can be singled out as the pivotal thinker in the emergence and development of the tradition. The reason for this status is the fact that both Hobbes's and Rousseau's theories are characterized by constitutive splits that can render them inspirational thinkers for both radical right and radical left. Locke, in this sense, is the closest figure to a liberal theorist "par excellence". Being a 20th century American philosopher, Rawls partakes in a similar status of foundational thinker in a different sense. Rawls's thought is commonly accepted to indicate the renaissance of liberal thought in our time. His theory of justice has inspired an astounding volume of discussion and reflection, which can be attested by the sheer volume of secondary literature dedicated to his work. 
In this essay, I discuss the way justice is conceptualized by Locke and Rawls. The task in hand calls for delineating the broader theoretical frameworks in which respective concepts take shape, and requires at least a brief note on the time gap separating the two. For the purpose of clarification, I also focus on some adjacent ideas such as freedom, equality, consent, rationality and contract, with special emphasis on the last two. I do not seek an exhaustive canvassing of the works by the thinkers, but limit my discussion to their seminal works; namely, The Second Treatise of Government by Locke, and A Theory of Justice by Rawls. In the case of Rawls, this restriction has added value, since the author's later works represents a change of trajectory through increased incorporation of communitarian ideas and modes of thinking.

A central sub-topic dealt with in the essay is depicting the concepts of justice in relation to the contractual elements in respective theories of the thinkers. The terminology used by Locke is based on the components of the state of nature, social contact and (civil) society. The state of nature, as a concept, represents a condition in which the state as a centralized arbitrator does not exist. On this line of theorizing, the individuals agree upon exiting this way of being through a social contract, and establishing civil society and the state. The idea of contact encountered here is formulated against the backdrop of broader assumptions on the state of nature in general and human nature in particular. Rationality, in Locke's theory, is both a defining feature of the individual and a central potency motivating this transition.

For Locke, human beings are free and equal. They have, and to some extent enjoy, natural rights, also in the state of nature. These are the rights to life, liberty, and property that are given by the law of nature, and recognized by virtue of rationality. Rationality also brings upon the capacity to be aware of the ills or shortcomings characterizing the state of nature, and to conceive a collective exit through individual rational consent. The outcome is the emergence of a unified legal system and a central arbitrating power, whose establishment is rational for each and every individual. Locke, in this sense, designates free and rational consent on the basis of equality as the foundation of legitimate political authority. In contrast, Rawls's foundational work takes place in a historical setting where the ideas of liberty and equality are largely accepted, also as the guiding principles of main social and political institutions.

The Rawlsian renaissance is rather focused on choosing among various broadly liberal schemes of justice, and with accommodating socio-economic concerns. Nonetheless, Rawls's social egalitarianism is subjected to the primacy he accords to basic liberties expressed in the first principle of justice. This principle provides that each person has the right to the most extensive set of basic liberties that are compatible with equal liberties for all.

Rawls derives his principles of justice from a suppositional setting of social contract termed "the original position". The underlying idea is as follows: If placed in these ideal - yet strictly hypothetical- conditions, rational individuals will choose the best scheme of justice available to them. The participants of the original position are situated on the basis of equality, and they are equally ignorant of their real-life positions in society. The principles of justice they agree upon will be rationally 
acceptable for each and every one of them, since it will reflect a rationally prudent choice instead of self-interested quest for gaining advantage for oneself or the group one represents.

In consequence we can argue that for both Locke and Rawls, contracting into a justly ordered society is rational, be it to achieve better protection for natural rights or to enjoy the benefits of social cooperation defined as such.

Keywords: John Locke, John Rawls, liberalism, liberal conception of justice, social contract, individual rights, freedom, equality, rationality.

\section{Giriş}

Toplum sözleşmesi kavramı liberalizm kadar modern siyasal düşünce üzerinde de önemli etkiye sahiptir. John Locke, Thomas Hobbes ve Jean-Jacques Rousseau gibi düşünürler, liberal geleneğin tarihsel serüveninde önemli kilometre taşlarını oluştururlar. Yine de hatırlanmalıdır ki, söz konusu isimlerin bu entelektüel ve siyasal hat üzerindekileri etkileri, kuramlarının içsel dinamiklerinden kaynaklanan nedenlerle farklılıklar gösterirler. Hobbes, siyasal iktidarı bireysel hak kavramı üzerinden meşrulaştırma konusunda öncüdür ancak mutlakiyetçi eğilimleri ve güçler birliği vb. görüşleri ile muhafazakâr düşünceye de kaynaklık etmiştir. Benzer biçimde Rousseau da liberal düşünce kadar sol ve sağ radikalizme de ilham vermiş bir yaklaşım ortaya koyar. ${ }^{1} \mathrm{Bu}$ anlamda Locke'un kuramının yaptığı etki hem liberal düşünce geleneğinin oluşumunda hem de bireysel haklar, sınırlı devlet, güçler ayırımı, dinsel hoşgörü vb. kurumsallaşmış alanlarda özel ve ayırt edicidir. John Rawls ise liberal düşüncenin 1970'lerde yaşadığı kuramsal Rönesans ile ilişkilendirilen etkili bir Amerikan felsefecisidir. Rawls ve Locke arasındaki ortaklık ve yakınlık, yaklaşık üç yüz yıl ile birbirinden ayrılan bu öncülük faaliyetiyle sınırlı değildir. Locke sözleşmeci liberalizmi temellendiren bir 17.yüzyıl düşünürü olmanın yanı sıra A.B.D.'nin siyasal kurumları ve düşünüşü üzerinde geniş etkiye sahiptir (Dunn 2008: 33).

Bu yazıda Locke ve Rawls'un adalet anlayışları karşılaştırmalı biz yaklaşımla ele alınacaktır. Sürdürülecek tartışmanın amacı, öncelikle her iki kuramın çerçeveleri genel hatlarıyla çizmek, ardından da her iki düşünürün de sıklıkla başvurduğu kimi ortak kavramların içerik ve işleyişlerini ortaya çıkarmaktır. Locke'un adalet kavrayışı üzerine yapılacak araştırma Yönetim Üzere İkinci Inceleme isimli üzerinde yoğunlaşırken, Rawls'un düşüncesi de Bir Adalet Teorisi'nde en kapsamlı formülasyonuna ulaşan erken dönem eserleriyle sınırlı biçimde ele alınacaktır. Her iki kuramda sıklıkla karşımıza çıkan eşitlik, özgürlük ve rasyonellik temaları üzerinde özel bir ağırlıkla durulacak; bu unsurlar hassas bir kıyastan ziyade bir arada düşünme çabası olarak ifade edilebilecek bir yaklaşımın eksenleri olarak ele alınacaklardır.

\section{John Locke’un Düşüncesinde Özgürlük ve Toplumsallık}

Locke'un kuramı, toplum sözleşmesi geleneğine karakterini veren yapısal unsurlarını içerir ve bu kuram ailesinde mevcut temel işleyişine uygun biçimde ilerler. Sözleşmeci düşüncenin unsurlarını kisaca belirtmek gerekirse:

1. Doğa durumu, insanların devlet ve (sivil) toplum öncesi yaşantısıdır. Klasik sözleşmeci düşünürlerin doğa durumunu tarihsel ya da antropolojik bir gerçeklik olarak tasavvur edip etmedikleri tartışmalıdır. ${ }^{2}$ Üzerinde daha yaygın olarak uzlaşılan düşünce kültürel modernliğin temel değerleri

\footnotetext{
${ }^{1}$ Karl Marks ve Carl Schmitt'in kuramları, Rousseau'nun radikal sol ve sağ düşünce gelenekler üzerinde etkisine örnek olarak gösterilebilir.

${ }^{2}$ Locke'un iddiası doğa durumunun tarihsel ve antropolojik bir gerçekliği olduğu şeklindedir. Bkz. Yönetim Üzerine İkinci Inceleme, 22-23.
} 
olan eşitlik ve özgürlüğün kurgusal bir doğa kavramına giydirildiği ve insanların doğadan gelen nitelikleri olarak meşrulaştırıldığıdır (Scanlon, 1982).

2. Toplum sözleşmesi, doğa durumunu geride bırakmanın aracı olarak hizmet eden ve bireysel onayın temsilini sağlayan mekanizmadır.

3. (Sivil) toplum ve devlet, kişiler doğa durumunda de facto sahip oldukları kimi hakları siyasal iktidara devrederek giriştikleri ortak yaşantının temel düzenleyici kurumlarıdır.

Bu üçlü yapı dâhilinde doğa durumunun hangi içeriklerle donatıldığı, sözleşme sonucu ortaya çıkacak devlet ve sivil toplumun niteliğini etkileyecek, siyasal iktidara atfedilen güç ve meşruiyet alanlarının sınırlarını çizecektir. Söz gelimi Hobbes doğa durumunu yaşamda kalma ve güvenlik kaygısıyla hareket eden kişilerin birbirlerine karşı savaşının ve sürekli bir ölüm korkusunun hâkim olduğu bir hal olarak tarif eder (Hobbes 1992: 94). Dolayısıyla, bu koşulların geride bırakılması büyük önem taşıyacak, merkezi bir siyasal yapı aracılı̆̆ıyla güvenlik sağlamanın acilliği, devlete yönelik hak talepleri ve sınırlandırmaları asgari bir düzeyde tutulacaktır. Leviathan'ın doğa durumunu tartışan sayfalarının edebi gücü ve canlı tasvirleri de bu koşullar altında yaşamın tahammül edilemezliği, dolayısıyla da mutlakiyetçi gücün meşruiyetini kurgulayan pasajlar olarak okunabilir. ${ }^{3}$

Hobbes'tan farklı olarak Locke, doğa durumunu pek çok açıdan daha makul bir hal olarak tarif eder. ${ }^{4} \mathrm{Bu}$ tarif esasen Hobbes'a benzer bir şekilde insanların temel kaygısının güvenliklerini sağlama ve varlıklarını sürdürme olduğu kabulüyle başlar. Ancak Lockecu dünyada doğa yasasından kaynaklanan kimi özel koşullar da mevcuttur. Doğa yasası herkese "elinden geldiğince" insanların geri kalanını korumak yönünde bir görev' yükleyerek barışa yönelik bir dinamik yaratır. (Strauss 2011: 259). Kendini koruma ile başkalarını koruma arasında öngörülen bu uyum, Locke'un doğanın sunduğu kaynaklara dair düşüncesiyle de desteklenir. Şöyle ki doğa durumunu niteleyen bolluk hali kit kaynaklar için kıyasıya mücadele ihtiyacını yumuşatarak insanlar arası çatışma potansiyelini de azaltır (Strauss 2011: 259).

Locke'un kuramında yaşam, özgürlük ve mülkiyet, doğa durumu çerçevesinde de doğal hukuk koruması altında bulunan tasarruflara karşılık gelirler. Sözleşme düşüncesine zemin oluşturan bireysel onay şartı ise bu hakların korunmadığı hatta genişletilmediği bir duruma geçişin kabul görmeyeceği anlamına gelecektir. Doğal haklar, tanım gereği, devlet öncesi durumda mevcut sayllırlar ve daha sonra oluşturulacak siyasal kurumların meşruiyeti için kıstas teşkil ederler. Locke bu anlamda "haksız ve adaletsiz otoriteye karşı direnme hakkı" ya da toplumun devlete onayını geri çekmesini olarak da tanımlanabilecek isyan hakkının üzerinde önemle durur (Dunn 2008: 43). Devletle sözleşmenin ilgası durumunda toplumsalın çözülmeyeceğine dair yargı, nihai noktada siyasi otoritenin tiranlaşma eğilimine karşı direnme konusunda önemli dayanak noktaları sunar.

Öte yandan Locke'un doğa durumu tasviri idealden uzak bir tablo çizer. Doğa durumu içinde insan yaşamı, korku ve tehlikelerle de doludur. Bunun temel nedeni ise insanların çoğunluğu doğa yasasının izleyicileri olmamalarıdır (Locke 2019: 132). Bu anlamda Locke Hobbes’ta rastladığımız türden daimi bir savaş halinde söz etmese de çatışma ve kaosun kuvvetli bir ihtimal olarak yer bulduğu bir tablo çizer.

Pozitif hukuk ve devlet öncesi yaşantıda insanların tabi olduğu kısıtlamaların temeli doğa yasasıdır. Kökenlerini geç ortaçağ düşüncesinde bulan bu anlayış, bir yandan dünyevi iktidarı aşan bir ilkeden kaynaklanan ve diğer yandan gerçek anlamda tam bir bağlayıcılığa sahip" normlar şeklinde

\footnotetext{
${ }^{3}$ Hobbes’un meşhur ifadesiyle, doğa durumunda insan hayatı “yalnız, yoksul, kötü, vahşi ve kısa sürer”. Bkz. Leviathan, s. 94.

${ }^{4}$ Hükümet Üzerine İkinci İnceleme'de yer alan tasvirler barış ve bolluk kadar savaş ve kıtlıkla da maluldür. Leo Strausss'un ifadesiyle Locke, kitabın ilk sayfalarında "ortaya attığı resmi ileriki sayfalarda yıkmaya” girişmiştir. Bkz. Doğal Hak ve Tarih, s. 259.
} 
tanımlanmıştır (Dumont 2000: 150-151). ${ }^{5}$ Doğa yasası kavramının kaynağında, doğru-yanlış, adil olan ve olmayan ayrımların herkes tarafından bilinebilen ve kaynağını tanrıdan alan ilkeler olduğuna dair düşünce yatar. Modern döneme gelindiğindeyse doğa yasasının toplumsal bütünden ziyade rasyonel bireyleri ele almaya başladığını ve devletin oluşumunun temel ilkelerini de insana içkin özellikler ve niteliklerden çıkarsamayı amaçladığını görürüz (Dumont: 151).

\section{Doğa Durumundan Devletli Topluma: Sözleşme ve Rasyonalite}

Locke'un düşüncesinde de doğa yasasının gerekleri eşit, özgür ve rasyonel birey fikrine dayandırılır. Yazarın ifadesiyle, "herkes veya her birey doğası gereği eşit ve bağımsızdır. Bu nedenle akıl insanlara, hiç kimsenin bir diğerinin yaşamına, sağlığına, özgürlüğüne ya da mülkiyetine karışma ya da izin verme hakkına sahip olmadığını ögretir" (Locke, 2004: 15). Burada altı çizilmesi gereken nokta, genel olarak doğa yasası anlayışında ve özel olarak da Locke'un düşüncesinde pozitif hukuk ve ahlak normları arasındaki ayırımın belirgin olmamasıdır. Lockecu doğa yasasının ahlaki niteliği kişilerin birbirlerini sadece araç olarak görmesini men eden kısıtlar şeklinde karşımıza çıkar ve devleti önceleyen koşullarda dahi bir tür toplumsallığın mevcut kabul edilmesi anlamına gelir. Lockecu norm dizgesinin hukukla kesiştiği yer ise onlara eşlik eden yaptırımlardır. Yazarın belirttiği gibi normun gücü ve bağlayıcılığı ancak yaptırımlar sayesinde sağlanabilir: "Tipk bu dünyanın insanlarla ilgili öteki yasatan gibi, doğal durumda doğanın yasaları da, onları uygulama, suçsuzu koruma ve saklama, suçsuza kötülük edenleri cezalandırma yetkisine sahip kimse bulunmasaydı tümden yararsız kalırdı" (Locke 2019: 17). Locke'un doğa düzeninde bu yaptırım yetkisi tek tek tüm bireylerin tasarrufunda bulunan ve - göreceğimiz üzere - toplum sözleşmesi aracılığıyla merkezi bir siyasal yapıya devredilecek yetkilerdir.

O halde doğa durumu kişilerin genel anlamda özgür olduğu ve insanın insan olmaktan kaynaklanan hak ve ödevlerinin yaptırımlarla korunduğu bir yaşantıya işaret eder. Ancak doğa durumunda bu haklardan yararlanılabileceği kesin değildir. Locke’un ifadesiyle: “...tüm insanlar baş olduğundan, herkes eşit olduğundan, çoğunluk hak dengesini, dürüstlü̆̈̈̈ gözetmediğinden ...(haklar) sürekli olarak başkalarının saldırısına uğrar... İnsanları, özgür olmakla birlikle korku dolu ve sürekli tehlike karşısında bulunan bu durumdan çıkmaya zorlayan işte budur" (Locke 2019: 131). Bu koşullar, insanların bir araya gelerek bir toplum oluşturmasına ve doğa durumunda sahip oldukları kimi yetkileri bir yönetim aygıtına devretmesine sebep olur. Yönetim Üzerine İki İnceleme’nin toplum sözleşmesi aracılığıyla devletin oluşturulma nedenlerini ayrıntılarıyla tartışır.

Locke'un tartıştığ1 ilkelerden ilki sistematik bir hukuk düzeninin tesis edilmesine duyulan ihtiyaçtır. "Doğal durumda, yan tutmayacak, tüm uyuşmazlıkları yerleşmiş yasalara uygun biçimde çözüme bağlama yetkesini elinde tutacak, varlı̆̆ kabul görmüş bir yargıç yoktur" (Locke 2019: 132).. Bunun yerine her bir birey doğa yasasını uygulamaya ve ihlalleri cezalandırmaya yetkili kılınmıştır. Merkezi yorum ve uygulamadan yoksunluğun yarattığı sakıncalar ilk olarak yasanın anlaşılabilmesi konusunda ortaya çıkar. Şöyle ki doğa yasası rasyonel yani akli yetilere sahip herkes için anlaşılabilirdir, ancak içeriği ve gereklerinin çoğu zaman incelenmeden kalır. Locke ikinci olarak kişilerin kendilerinin taraf oldukları anlaşmazlıklarda nesnel davranamayacağı, çoğu zaman tutku ve öç isteğiyle adaletsizliğe savrulacaklarını ileri sürer (Locke 2019: 132). Üçüncü olarak ise yaptırımların bireysel inisiyatife dayanması ile güç dinamikleri yeniden denkleme girecektir. Şöyle ki, doğa yasasını ihlal edenler güçleri yetiyorsa cezasız kalabilir, kendilerine ceza uygulamaya çalışanları zorbalıkla bastırabilir, hatta onlara zarar verebilirler (Locke 2019: 133). Bu tablo haklılığın güçlülükten ayırt edilemediği ve kişilerin birbirine yapabileceklerinin sınırının gücünün sınırında çizildiği Hobbescu doğa durumu ile rahatsız edici bir benzerlik içindedir.

\footnotetext{
${ }^{5}$ Doğal hukuk kuramlarının kökenleri geç ortaçağ ve Aquinas'a değin izlenebilse de bu gelenek modern çağlarda önemli bir dönüşüm geçirmiştir. Bkz. Louis Dumont, "Bireycilik Üzerine Denemeler: Doğuş. XIII. Yüzyıldan Başlayarak Siyaset Kategorisi ve Devlet", s.151.
} 
$\mathrm{Bu}$ türden negatif sonuçlardan kaçınılması kişilerin hak sahibi bireyler olarak kabul görecekleri bir toplum yaşantısının ve bu doğa yasasının gereklerini merkezi bir elden sağlayacak devletin inşası ile sağlanacaktır. Devletin meşruiyetinin asgari kıstası da kaynağını doğa durumundan alan ve sözleşme sonrası düzene devreden yaşam, özgürlük ve mülkiyet haklarını korumasıdır. Locke bireysel hakları doğal hukuk kaynağından türetir; böylelikle de da devlet ya da pozitif hukuk tarafından verilmeyen ve yine bunlarca elinden alınamayacak bir hak kategorisi tanımlar. Bu görüş Locke'un insanları özgür ve rasyonel kabul edilen başlangıç önermeleri tarafindan da desteklenir. Rasyonel kişilerin, haklarını ellerinden alçak ya da özgürlüklerini kısıtlayacak yasa ve kurumlara kendi rızalarıyla tabi olmaları beklenemez. O halde devlet ve sivil toplumun vaadi; doğa durumunda hali hazırda sahip olunan hakların garanti altına alınması ve genişletilmesi; bir diğer deyişle, doğa yasasının daha büyük bir güç ve istikrarla uygulanmasıdır.

\section{John Rawls ve Adalet'in Kurgusal Kökenleri}

Bir 17. Yüzyıl figürü olarak Locke'un en önemli gündemi, modernliğin çağ dönümünde insanların eşitliği ve özgürlüğü fikirlerinin kuruculuğunu üstlenmektir. Locke hiyerarşik siyasal yapılara meşruluğunu veren soy ya da ilahi düzen anlayışlarının karşısına, Aydınlanma düşüncesiyle değer ve ağırlık kazanan doğa fikri ile çıkar. Doğa yasası özelinde ise Locke devletten ziyade bireyi kimi özelliklerle donatan; toplumsal ve siyasal kurumları da bu kaynaktan türeten modern bir biçim sunar.

Bir Adalet Teorisi'nin yayımlanmasını takip eden tartışmalarda, Rawls'un da 20. yüzyılda liberalizm için benzer bir temellendirme çabasına giriştiği iddia edilmiştir. Burada ayırt edici nokta Rawls'un kuramının eşitlik ve özgürlüğün yaygın kabul gördüğü ve temel toplumsal yapıların düzenleyici ilkeleri olarak kurumsallaştığı bir dönem ve coğrafyada ortaya atılmış olmasıdır. Yazarın amacı bu kavramları başlangıç noktası kabul ederek soyuttan somuta doğru ilerlemek ve kendi içinde tutarlı bir normlar bütünü ortaya koymaktır. Bu çabanın ana hedefi, 'temel yapı' adı verilen anayasa, ekonominin ana prensipleri ve toplumsal düzenlemeler gibi 'büyük kurumlar' açısından adil kabul edilecek ve yaşamını bu kurumlar dâhilinde sürdürecek kişiler tarafından onaylanacak kuralları tespit etmektir (Rawls 2017: 35). Bir başka deyişle Rawls, toplumsal kurumları adaletini katılımcıların perspektifine göre değerlendireceğimiz bir kuramsal yapı ortaya koymaktadır (Pogge 2002: 62).

Yukarıda belirtildiği üzere Locke'un eserlerinde doğa durumunun tarihsel veya antropolojik bir gerçekliğe karşılık gelip gelmediği meselesi yeterince açık biçimde ifade edilmemiştir. Rawls'un kuramında ise doğa durumunun eşdeğeri olarak ifade bulan ve kurgusal bir düzenek olduğu açıça vurgulanan 'başlangıç durumu' kavramıyla karşılaşırız (Rawls 2017: 40, 41, 147). Başlangıç durumu, özel biçimde tasarlanmış koşullar altında gerçekleştirilecek varsayımsal bir sözleşmeye verilen addır. Bu düzenekte adil ilkelere ulaşılması, katılımcıların toplumsal konumlarını belirleyen kimi değişkenler kendilerinden 'bilgisizlik peçesi' aracılığıyla gizlenmesiyle sağlanır. Rawls'un gerekçelendirmesini izlersek: "Seçimin bu şekilde yapılmış olması doğal bir şans veya beklenmedik durumlar tarafindan belirlenen tercih/seçim ilkelerinin hiç kimsenin lehine ya da aleyhine olmamasını sağlar. Herkes benzer biçimde konumlandiğında hiç kimse kendi lehine olan ilkeleri biçimlendirme gücüne sahip olamaz ve dolaylsıyla adalet ilkeleri bir pazarliğın ve adil bir anlaşmanın sonunda oluşur" (Rawls 2017: 41).

'Hakkaniyet olarak adalet', böylelikle, eşit ve özgür kişilerin özel olarak belirlenmiş koşullar altında seçeceği ilkeler zemininde tanımlanır. Locke'tan farklı olarak Rawls kuramında doğa durumundan sivil toplum ve devlete geçiş temasını ele almaz. Düşünürün amacı bütünüyle varsayımsal bir düzenek aracılı̆̆ıyla belirli normatif ilkelere ulaşmaktır. Rawls, kavram üzerinde yapılacak çalışmanın esasını 'başlangıç durumunda hangi ilkelerin seçilmesi gerektiğinin açıkça belirlenmesi' olarak ifade eder (Rawls 2017: 43). Bu ilkeler daha sonra adım adım somutlaştırılarak anayasal, iktisadi, siyasal vb. kurumları düzenleyecek bir kurallar dizgesine dönüştürülecektir. 
Başlangıç durumu katılımcılarını eşitlik, özgürlük ve rasyonellik nitelikleriyle donatılmıştır. ${ }^{6}$ $\mathrm{Bu}$ bağlamda eşitlik ve özgürlük ayrı ayrı korunması gereken değerler olmanın yanında, bir araya gelerek yeni anlam ve gereklilikler taşıyan ilkeler olarak da ele alınırlar. ${ }^{7}$ Söz gelimi eşitlik, özgürlüğün anlaşılma biçimine içkindir ve eşit özgürlükler ya da özgürlükte eşitlik olarak adlandırılabilecek bir kavrama karşılık gelir. Bu durumun ilk göstergesi başlangıç durumu tarifinde ortaya çıkar: "[B]ir grubun içindeki insanın bir defada ve her zaman bunların arsındakilerden [toplumun kuruluşş̧artlarından] neyin adil veya neyin gayri adil olduğunu hesaba katması gerekir. Rasyonel insan varsayımsal bir durum olan eşit özgürlük içinde yaptı̆̆ seçimi, mevcut durum içinde bu tercih/seçim sonucunun adalet ilkelerinin belirlediği bir çözüm olduğunu varsayar" (Rawls 2017: 40). ${ }^{8}$

İlaveten özgürlük, başlangıç durumu müzakerecilerinin üzerinde ulaşacağı iki adalet ilkesinden ilkidir. Teori' de sunulan formülasyonu' aktaracak olursak:

Özgürlük İlkesi: Her kişi, herkesin benzer özgürlük sistemiyle bağdaşan en geniş eşit temel özgürlükler sisteminin toplamı üzerinde eşit hakka sahiptir (Rawls 2017: 279).

Fark İlkesi: Sosyal ve ekonomik eşitsizlikler şöyle düzenlenmelidir. Bunlar şu iki şeydir: a) herkesin avantajının kabul edilebilir olduğu beklentisi ve b) ekli pozisyonların ve görevlerin herkese açık olmas1 (Rawls 2017: 90).

Bunlardan özgürlük ilkesi maksimizasyon mantığını izler, çünkü eşitlik temelinde uygulanabilme vb. bir çatışma söz konusu değilse, daha dar kapsamlı bir dizgenin tercih edilmesi rasyonel değildir (Rawls 2001a: 194). Özgürlük ve fark ilkelerinin sıralanma düzeni de normatif bir hiyerarşiye tekabül eder. Hakkaniyet olarak adalet kavramının bütün formülasyonlarında birinci madde, ikincisi karşısında önceliğe sahiptir. Daha açık bir ifadeyle, sosyo-ekonomik alanı ilgilendiren konular ilk ilkeye tabidirler ve özgürlük bu tür gerekçelerle değil sadece diğer özgürlüklerin eşitlik temelinde korunabilmesi adına sınırlandırılabilir.

Yukarıda da değinildiği üzere hakkaniyet olarak adalet kuramı, toplumsal kurumların etkiledikleri kişilere hangi oranda adil davrandıklarını değerlendiren bir adalet kıstasının ortaya konması ve doğrulanmasını hedefler. Söz konusu hedef ise değerlendirme görevi için tasarlanmış bir ölçeği gerekli k1lar (Pogge 2002: 50, 51). Rawls'un bu amaç doğrultusunda başvurduğu analitik araç 'birincil değerler' kavramıdır. Bunlar bireylerin farklı çıkar ve beklentilerine rağmen yaşam planlarını uygulamak üzere ihtiyaç duydukları kimi haklar ve kapasitelere karşıllk gelirler ve bir 'değerler indeksi' aracılığıyla kavramsallaştırılırlar (Rawls 2017: 120).

Değerler indeksi en genel anlamda haklar, özgürlükler, firsatlar, gelir, refah ve kendine saygının toplumsal temeli gibi unsurlardan oluşurlar. Bunlar aralarındaki olası tüm kimlik ve çıkar farklılıklarına rağmen tüm vatandaşların rasyonel bir hayat planı oluşturmak, sürdürmek ve bu planları değiştirebilmek için ihtiyaç duydukları şeylerdir (Rawls 2001b: 58)

Rawls'un değerler indeksine daha yakından baktığımızda ise ilave iki özellik öne çıkar. Bunlardan ilki birincil değerlerin toplumsal niteliği; yani özgür, eşit ve rasyonel kişilerin toplumsal işbirliği tercihleri sonucu ortaya çıkmış imkân ve kapasiteler olmasıdır. İkincisi ise rasyonalite kavramının birincil değerlerin maksimizasyonunu talep etmesidir. Daha açık bir ifadeyle, kişiler

\footnotetext{
${ }^{6}$ Bir Adalet Teori'sinde dile getirilen hakkaniyet düşüncesi bizatihi özgürlüğün insanın özne vasfindan çıkarsanabilecek evrensel bir değer olduğunun kabulü üzerinde yükselir. Ayrıntılı bir tartışma için bkz. Özlem Denli "John Rawls ve Philip Pettit'in Özgürlük Anlayışları: Cumhuriyetçiliğin Yalnızlığı”.

${ }^{7}$ Bir Adalet Teorisi’nin IV Kısımı 'Eşit Özgürlük' tartışmasına ayrılmıştır. Bkz. s. 223.

${ }^{8}$ Ek bana ait.

${ }^{9}$ Rawls, Bir Adalet Teorisi çerçevesinde iki adalet ilkesinin birden fazla formülasyonuna yer verdiğini belirtir. Daha erken bir ifade şöyledir: "Her kişi başkalarının özgürlüklerinin sunulduğu şemadakiyle yarışabilen en geniş temel özgürlükler şemasına benzer eşit haklara sahiptir”. Bkz. s. 89, 90.
}

\section{Turkish Studies - Social Sciences}

Volume 14 Issue 4, 2019 
seçtikleri amaçlar ve 'uzun süreli hayat planları' ne olursa olsun, birincil değerlere mümkün olan en geniş çerçevede sahip olmayı isteyeceklerdir (Rawls 2017: 120, 121). Bu anlamda Locke'un düşüncesinde yaşam, özgürlük ve mülkiyet olarak ifade bulan doğal haklar, Rawls'un kuramında da adalet ilkeleri ve temel değerler kavramları aracılığıyla kavramsallaştırılan ve en geniş kapsamla donatılan bir hak ve özgürlükler dizgesi olarak karşımıza çıkar.

\section{Rawls'un Kuramında Çatışma ve Rasyonalite}

Toplumun insanlar arasında bir işbirliği sistemi olarak anlaşılması (Rawls 2017: 38), özgürlükte eşitlik düşüncesini rasyonalite kavramı ile de birbirine bağlar. Somut toplumsal ilişki ve kurumları düzenlemesi öngörülen normlar bu üç varsayımın gereklerini ortaya koymak üzere tanzim edilen başlangıç durumunda seçilecek ilkelerdir (Rawls 2017: 40). Bu özel bağlamda rasyonalite, kişilerin özçıkarlarından bağımsız bir şey olarak ele alınmaz; aksine, her bir temsilcinin çıkacak sonuçları kendi lehlerine olacak biçime sokmaya çabalayacağı düşüncesi üzerinden kurgulanır. Bilgisizlik peçesinin analitik bir araç olarak işlevi, bu bireysel eğilimin toplamda adil sayılacak sonuçlar ortaya çıkarmasını sağlamaktadır.

Rawls ile Locke'un kıyaslanabilir bir diğer yönü de çatışma ve rasyonalite arasında kurdukları ilişkidir. Locke ile benzer biçimde Rawls da toplumsal yaşantının düzenlenmesinin öncesinde kişiler arasında çeşitli çatışma dinamiklerinin var olduğunu belirtir ve çatışma ihtimalinin hiçbir zaman tamamen ortadan kalkmayacağını söyler (Rawls 2017: 32-33). İyi düzenlenmiş toplumlar esasında kişiler arasındaki çatışma potansiyelini düzenleyerek bu vasfı kazanırlar. O halde adaletin işlevi farklı kimlikler, beklentiler ve çıkarları olan insanların her birinin özgürce onaylayacakları bir kurumsal düzen inşa etmektir.

Rasyonel kişiler kendi amaçlarını aramayı sürdürmek için toplumsal işbirliğinin getirdiği faydalardan en üst derecede yararlanmayı amaç edinirler (Rawls 2001a: 190). Hakkaniyet olarak adalet, her bir kişinin avantaj ve yükümlülüklerin yine herkes tarafindan makul kabul edileceği adil bir dengeye ulaştıracak böylelikle de çatışmaları da toplumsal bütünlüğü bozmayacak bir seviyede tutacaktır. Hakkaniyet olarak adalet kuramı açısından kabul görecek asgari standartlar: a) kişilerin birbirleriyle olan ilişkilerinde belirli davranış kurallarını ve bunların bağlayııılığını kabul etmeleri ve b) bu kişilerin büyük bir bölümünün bu kurallara uygun davranmasıdır (Rawls 2017: 32). Diğer insanların varlığı kişilerin tüm istediklerini elde edemeyecekleri anlamına gelir. Bu anlamda adalet fikri rasyoneldir, çünkü kişileri bu gerçekle uzlaştıran, toplumu inşa ve muhafaza eden bir işleve sahiptir.

Birey açısından bakıldığında ise adalet duygusu kimi şahsi kayıplara razı olmak ve kişisel amaçlar veya önceliklere getirebilecek kimi sınırlamaları meşru kabul etmek anlamına gelecektir. Rawls bu yargısını 'adil kurumlara destek olma görevi' olarak tanımlar ve iki başlık altında ele alır: "Birincisi adil kurumlar mevcut olduğunda ve bize uygulandiğında, bunlara itaat eder ve kendi üzerimize düşeni yaparı ve ikincisi eğer mevcut değil ise, adil düzenlemelerin kurulmasına yardım ederiz. Toplumun temel yapısı eğer adil ve koşullar içinde bunun beklenmesi olabildiğince makul ise, bu durum, herkesin kendisi için gerekli olanı yapmasının doğal ödevi olması fikrini takip eder" (Rawls 2017: 362). Sonuç olarak hem Locke'un hem de Rawls'un kuramlarında rasyonel bireyler daimi bir kayba uğrama halinde toplumsal işbirliğine girmeyi reddedecektir. Locke açısından toplumsal işbirliğine geçiş, doğa yasasının tanımladığı özgürlüklerin daha büyük bir güç ve istikrarla korunabilmesi için gerçekleşir. Bireylerin özgür rızalarıyla doğa durumunu terk etmelerine benzer bir tercih anı Rawls için de farklı ve birbirleriyle rekabet halinde adalet anlayışları arasında yapılacak seçime tekabül eder.

Rawls açısından daimi kayba uğramanın toplumsal ilişki ve kurumlardan desteğin çekilmesi ile ilişkisi iki ana tema zemininde ele alınabilir. Yazarın altını çizdiği ilk düşünce bireysel konumların toplam toplumsal faydanın arttırılması karşısında önceliğidir. Ortak kurumsal yapının düzenleyici 
ilkeleri tek tek bireyler için rasyonel olması; yani, toplumsal yaşamdan gelen faydanın kişiye yüklediği sorumluluk ve kısıtlamalara kıyasla ağır basması beklenir. Rawls'un ifadesiyle: "Her bir insan kendi menfaatlerini, kendi iyi ve değer kavramın gelişstirme yeterliliğini korumayı arzu ettiğinden kimsenin daha büyük ve net tatmin dengesi sağlamak amacıyla kendisi için daimi bir kayba razı olmak için herhangi bir nedeni olamaz. Güçlü ve sonsuz yardımseverliğin eksik olması, rasyonel bir insanı sadece temel yaplyı kabul etmemeye yöneltir, çünkü bu durum o kişinin hak ve menfaatleri üzerinde kalıcı bir etkisi olmasına bakılmaksızın cebirsel avantajlar toplamını azamileştirir" (Rawls 2017: 43).

İkinci olarak da adalet ilkelerinin kişiler arası kıyaslama yapmaya imkân verebilmesi ve ortaya çıkardığı sonuçların katılımcıların gözünden kabul edilebilmesi gereklidir (Pogge 2001: 60). Bu kıstas Rawls tarafindan şu şekilde dile getirilir: "Bir kişsinin nesnel birincil değerler endeksi tarafindan ölçülen daha düşük pozisyonu, onun öz saygısını ve verili pozisyonunu yaralayacak kadar büyük olduğunda, biz onun kaybetme duygusuna sempati duyartz. Gerçekte biz toplumun bu iyiler içinde bu tür eşitsizliklere izin vermiş olmasına ve mevcut şartlar altında bu şartların yardımcı olmamasına ama kendine saygının kaybına neden olmasına ve bunların hasetlik yapmasına içerleriz" (Rawls 2017: 564). Görüldüğü üzere temel kurumsal yapıyı düzenleyen normların adaletini, toplumsal hiyerarşinin en dezavantajlı konumlarını işgal eden kişilerin konumu perspektifinden değerlendirir (Pogge 1989: 109). Temel değerler açısından bireyler arasında yapılacak kıyaslama bu anlamda hakkaniyetli bir toplumda kabul edilebilir farkları da tartışmaya açan eşitlikçi bir anlayışla birleşir (Tan 2000: 159).

Görüldüğü üzere, hem Locke ham de Rawls için adil toplumsal işbirliğinin kıstasları eşit ve özgür kişilerin içinde bulundukları duruma ilişkin rasyonel değerlendirmeleri sonucunda ortaya çıkar. Locke, özgürlük kavramını daha genel bir anlamda ele alır ve doğa durumunda sahip olunan özgürlükleri daha büyük bir güç ve tutarlılıkla koruyacak bir devlet düzenini rasyonel ve adil kabul eder. Rawls açısından ise devletli toplum zaten veri alınan bir durumdur. Rawls için rasyonalitenin işlerliği, birbirinden farklı ve rekabet halinde çeşitli adalet ilkeleri arasından, kişilere en yüksek derecede hakkaniyetle muamele edecek kurumsal düzeneği tasarlarken ve seçerken ortaya çıkar.

\section{Sonuç}

Her biri kendi döneminde liberal düşünce geleneğinin en önemli temsilcisi kabul edilen Locke ve Rawls, insanların ortak yaşamlarını eşitlik ve özgürlüğe dayalı bir adalet anlayışı çerçevesinde düzenlenmesi gerektiğini söylerler. Her iki düşünür için de kişilerin özgürce onaylamayacakları bir siyasal ve toplumsal düzen içinde yaşamaları, bir tür zorlama hatta gasp durumuna tekabül eder. Özgürlük, Locke için nispeten genel terimlerle tartışılan ve bir eşit özgürlük hali olan doğa durumundan devletli topluma devreden temel bir haktır. Rawls ise daha somut bir kavramsallaştırma sunar ve mümkün olan en geniş kapsamla, herkese eşit biçimde sağlanabilecek bir özgürlükler dizgesinden söz eder. Hakkaniyet olarak adalet kuramının ayırt edici yanı ise özgürlükleri korumak ve gerçekleştirmek için toplumsal eşitlik lehine bir düzeltme talep eder sosyal liberal bir anlayış sunmasıdır (Öztürk 2016: 69). Böylelikle, toplumsal kurumların insanlara nasıl muamele ettiğini değerlendirmek üzere kurgulanan adalet ilkesi, özgürlüklerin biçimsel anlamını aşarak, sosyoekonomik meseleleri özgürlüklerin değeri sorusunu da kapsayacak bir anlam ve içerikle yeniden tartışmaya açar.

\section{KAYNAKÇA}

Denli, Ö. (2018). "John Rawls ve Philip Pettit'in Özgürlük Anlayışları: Cumhuriyetçiliğin Yalnızlığı", Felsefelogos, Say1: 69, s. 175-186

Dumont, L. (2000). "Bireycilik Üzerine Denemeler: Doğuş. XIII. Yüzyıldan Başlayarak Siyaset Kategorisi ve Devlet", Devlet Kuramı, (ed.) Cemal Bali Akal, Ankara: Dost Kitabevi Dunn, J. (2008). Locke, İstanbul: Altın Kitaplar

\section{Turkish Studies - Social Sciences}

Volume 14 Issue 4, 2019 
John Locke ve John Rawls'un Kuramlarinda Adalet Düşüncesi: Sözleşme ve Rasyonalite 1445

Hobbes, T. (1992). Leviathan, İstanbul: Yapı Kredi Yayınları

Locke J. (2019). Yönetim Üzerine İkinci İnceleme, Ankara: Serbest Kitabevi

Pogge, T. (2006). Küresel Yoksulluk ve Insan Haklarl, İstanbul: İstanbul Bilgi Üniversitesi

Pogge, T. (1989). Realizing Rawls, Ithaca: Cornell University Press

Rawls, J. (2017). Bir Adalet Teorisi, Ankara: Phoenix.

Rawls, J. (2001a). Collected Papers, Cambridge: Harvard University Press

Rawls, J. (2001b). Justice as Fairness: A Restatement, Cambridge: Harvard University Press

Öztürk, A. (2016). Cumhuriyetçilik ve Liberalizm, Ankara: Doruk Yayınları,

Scanlon, T.M. (1982). Contractualism and Utilitarianism, Utilitarianism and Beyond, (ed.) Amaratya Sen, Bernard Williams, Cambridge: Cambridge University

Smits, K. (2009). Applying Political Theory: Issues and Debates, London: Palgrave

Strauss L. (2011). Doğal Hak ve Tarih, İstanbul: Say Yayınları

Tan, K.C. (2000). Toleration, Diversity and Global Justice, Pennsylvania: Pennsylvania University Press. 